\title{
ОРГАНИЧЕСКОЕ ВЕЩЕСТВО ДОМАНИКИТОВ ТИМАНО-ПЕЧОРСКОГО БАССЕЙНА - УСЛОВИЯ ПРОЯВЛЕНИЯ ГЛАВНОЙ ФАЗЫ НЕФТЕОБРАЗОВАНИЯ
}

Бушнев Д. А., Бурдельная Н. С., Шадрин А. Н., Фадеева Н. П., Смирнов М. Б.

\begin{abstract}
Аннотация
Проведено комплексное исследование доманикоидных отложений Тимано-Печорского бассейна. На основе изучения состава углеводородов биомаркеров, химического строения керогена, изотопного состава углерода, литологических особенностей пород, данных пиролиза Rock-Eval, a также данных по содержанию битумоида и Сорг в породах раскрыты геохимические особенности протекания главной фазы нефтеобразования в доманиковых отложениях. Главная фаза нефтеобразования в доманиковых отложениях соответствует интервалу значений Тмакс 435-450 оС. В этом интервале значений Ттах наблюдаются максимальные значения битумоидного коэффициента betaХБ, которые достигают 30 \%. Анализ совокупности данных по распределению полициклических биомаркеров в породах доманика, битуминологических данных и результатов Rock-Eval позволил определить граничные значения биомаркерных коэффициентов зрелости при изучении катагенеза органического вещества доманика. Приводятся данные об изотопном составе углерода битумоида доманика и его фракций, показана бимодальность распределения значений delta13С битумоида доманика.
\end{abstract}

\section{Ключевые слова:}

органическое вещество, доманиковые отложения, Тимано-Печорский бассейн, битумоид, углеводородные биомаркеры, катагенез, изотопный состав углерода 
УДК: 550.4

\title{
ОРГАНИЧЕСКОЕ ВЕЩЕСТВО ДОМАНИКИТОВ ТИМАНО-ПЕЧОРСКОГО БАССЕЙНА - УСЛОВИЯ ПРОЯВЛЕНИЯ ГЛАВНОЙ ФАЗЫ НЕФТЕОБРАЗОВАНИЯ
}

\author{
(C) Д.А.Бушнев ${ }^{1}$, Н.С.Бурдельная ${ }^{1}$, А.Н.Шадрин ${ }^{1}$, Н.П.Фадеева ${ }^{2}$, М.Б.Смирнов ${ }^{3}$ \\ ${ }^{1}$ ИГ ФИЦ Коми НЦ УрО РАН, 167982, Сыктывкар, ул. Первомайская, 54, Россия \\ ${ }^{2}$ МГУ им. М.В.Ломоносова, г. Москва \\ ${ }^{3}$ ИНХС РАН, г. Москва \\ E-mail: boushnev@geo.komisc.ru
}

Поступила в редакцию ...

Проведено комплексное исследование доманикоидных отложений ТиманоПечорского бассейна. На основе изучения состава углеводородов биомаркеров, химического строения керогена, изотопного состава углерода, литологических особенностей пород, данных пиролиза Rock-Eval, а также данных по содержанию битумоида и $\mathrm{C}_{\text {орг }}$ в породах раскрыты геохимические особенности протекания главной фазы нефтеобразования в доманиковых отложениях. Главная фаза нефтеобразования в доманиковых отложениях соответствует интервалу значений $\mathrm{T}_{\max } 435-450{ }^{\circ} \mathrm{C}$. В этом интервале значений $\mathrm{T}_{\max }$ наблюдаются максимальные значения битумоидного коэффициента $\beta^{\text {ХБ}}$, которые достигают 30 \%. Анализ совокупности данных по распределению полициклических биомаркеров в породах доманика, битуминологических данных и результатов Rock-Eval позволил определить граничные значения биомаркерных коэффициентов зрелости при изучении катагенеза органического вещества доманика. Приводятся данные об изотопном составе углерода битумоида доманика и его фракций, показана бимодальность распределения значений $\delta^{13} \mathrm{C}$ битумоида доманика.

Ключевые слова: органическое вещество, доманиковые отложения, ТиманоПечорский бассейн, битумоид, углеводородные биомаркеры, катагенез, изотопный состав углерода

Развитие нефтегазоносной области на востоке европейской части России связано с именем крупнейшего учёного, основателя отечественной нефтяной геологии Ивана 
Михайловича Губкина [Конторович, 2017]. Он предавал важное значение поиску и разведке новых нефтяных и газовых месторождений и на основании детального изучения истории развития территории, стратиграфических данных, а также локальных нефтепроявлений. Он выделил Урало-Волжскую нефтеносную область, в последствие включающую Волго-Уральскую, Тимано-Печорскую и Прикаспийскую нефтегазоносные провинции [Губкин, 1932]. Именно И.М. Губкин определил основные направления работ в Ухтинском районе и рекомендовал тщательно исследовать его нефтеносность.

Термин «доманик» в узком смысле этого слова обозначает битуминозные отложения семилукского горизонта среднефранского яруса, представленные переслаиванием глинисто-кремнистых карбонатных пород, обогащённых органическим веществом (ОВ). Согласно известным данным для стратотипичных разрезов доманика Ухтинского района характерно содержание органического углерода 2-16 \% [Бушнев, 2009]. Накопление ОВ отложений доманика происходило в условиях аноксии бассейна седиментации как в Тимано-Печорском [Бушнев и др., 2015, 2016], так и в ВолгоУральском бассейне [Полудеткина и др., 2017, Смирнов, Полудеткина, 2018, Смирнов и др., 2020]. Говоря о доманикитах в более широком смысле слова обычно рассматриваются отложения франского, фаменского, вплоть до раннекаменноугольного возрастов битуминозные и обогащённые органическим веществом [Баженова и др., 2008].

Объектом настоящего исследования стали высокоуглеродистые породы позднедевонского возраста из керна скважин, пробуренных в разных частях ТиманоПечорского бассейна, а также образцы из ряда естественных обнажений. Целью исследований является анализ комплекса данных по геохимии ОВ этих нефтематеринских пород при учёте их литологических характеристик.

Экспериментальная часть.

Содержание органического углерода $\left(\mathrm{C}_{\text {орг }}\right)$ определялось в нерастворимом в соляной кислоте остатке породы с использованием «Экспресс-анализатора на углерод АН7529».

Битумоид экстрагировался хлороформом в аппарате Сокслета в течение 40 часов. Элементная сера удалялась из экстракта добавлением в приёмник губчатой меди в процессе экстракции.

Фракционирование битумоида осуществлялось путём предварительно осаждения асфальтенов н-гексаном и последующего их удаления. Полученная мальтеновая фракция разделалась на аполярную (масла) и полярную (смолы) на колонке с оксидом алюминия при элюировании 20\% раствором дихлорметана в н-гексане и смесью дихлорметан-этанол 
(1/1), соответственно. Аполярная фракция разделялась на насыщенную и ароматическую на колонке с силикагелем при элюировании н-гексаном и бензолом соответственно. Анализ углеводородных фракций (насыщенной и ароматической) осуществлялся методами газовой хроматографии (ГХ) и хромато-масс-спектрометрии (ХМС).

Газовая хроматография выполнялась на приборе Кристалл-2000М с использованием капиллярной колонки, а хромато-масс-спектрометрия на приборе Shimadzu QP2010 Ultra на колонке DB-5, 30 м × 0,25 мм, толщина слоя неподвижной фазы 0,1 мкм.

Пиролиз по методу Rock-Eval был выполнен в лаборатории геохимии пластовых нефтей ОАО “ТомскНИПИнефть” Р.С. Кашаповым с использованием прибора Rock-Eval 6 Turbo.

Исследования изотопного состава углерода (ИСУ) керогена, нефракционированного битумоида и его фракций производились с использованием массспектрометра Delta V Advantage (Thermo), сопряженного с элементным анализатором Flash ЕА. Оператор И.В. Смолева.

\section{РЕЗУЛЬТАТЫ И ИХ ОБСУЖДЕНИЕ}

Породы доманика и их литологические особенности

Для настоящего исследования была отобрана коллекция кернового материала и образцов из естественных отложений среднефранского-раннефаменского возраста, содержащих повышенные концентрации $\mathrm{C}_{\text {орг }}$.

Изученные породы представлены тонкослоистыми, в различной степени глинистыми, битуминозными шламовыми и шламово-мелкобиокластовыми известняками. Как исключение, отмечен единственный образец углеродисто-глинисто-известкового сланца.

Биокластовый материал пород состоит преимущественно из не определимого тонкоперетертого шлама. Крупный органогенный детрит, как правило, редок и породообразующим является лишь в единичных случаях. Наиболее часто встречаемыми остатками организмов являются тентакулиты. Меньшее распространение имеют пелециподы, и, значительно реже, наблюдаются радиолярии, раковинки остракод, фрагменты трилобитов и спикулы губок. Фауна располагается по плоскости напластования и равномерно распространена по толще породы, обычно без образования скоплений. 
Для всех образцов характерно наличие тонкой слоистости, обусловленной взаиморасположением лито- и/или биокластового материала. Следует отметить отсутствие биотурбации осадков, а в породах с тентакулитами - однонаправленной ориентировки остатков организмов.

Кроме глинистой составляющей в породах всех возрастов может встречаться привнесенный кварцевый материал алевро-псаммитовой размерности в количестве до 5 \%. Общее содержание терригенной примеси обычно не превышает 10-15 \%, крайне редко достигая $35 \%$.

В отдельных случаях отмечается частичное (до 5 \%) окремнение породы, захватывающее как цемент, так и органические остатки. В первом случае, морфологически это проявляется в формировании кремневых образований удлиненной сложной формы размерами от 0.01 мм до 0.1 мм. Располагаются они или вдоль определенного прослоя, в отдельных случаях почти формируя кремневый прослой, или хаотично в виде мелких образований размерами порядка 0.01-0.05 мм по всему объему породы. Окремнение крупного биокластового материала не полное - обычно сохраняются не измененные участки скелета карбонатного состава. Органические остатки шламовой размерности нередко изменены полностью.

Характерной особенностью изученных пород является наличие тонкокристаллического пирита. Форма выделения - одиночные кристаллы от 0.01 мм до 0.03 мм и агрегаты от 0.03 мм до 3 мм. Располагаются обычно хаотично по породе, реже вдоль одного прослоя и/или внутри органических остатков. Общее количество по породе не превышает 1 \%. В единичных случаях в незначительном количестве встречается сидерит в виде мелких конкреций (0,05-0,3 мм) или тонкозернистых образований. Часто в породах наблюдаются новообразованные кристаллы карбоната преимущественно ромбической формы, размерами порядка 0,05 мм и в количестве до 1-2 \%.

Несмотря на разные возраста, исследуемые породы имеют близкие литологические характеристики и, по всей видимости, формировались в сходных условиях. Характер слоистости пород, состав и гранулометрия терригенной примеси, качество и количество остатков организмов свидетельствуют об осадконакоплении в пределах относительно глубоководного морского бассейна на значительном удалении от береговой линии и спокойном гидродинамическом режиме без ярко выраженных течений [Flügel, 2004]. Отсутствие массовой и разнообразной бентосной фауны и биотурбации осадка указывает на неблагоприятные условия для жизни. Встречаемые остатки обитавших на дне организмов, скорее всего, являются привнесенными. Полученные результаты хорошо 
согласуются с существующими палеогеографическими построениями для соответствующих возрастов [Тимано-Печорский..., 2000].

Битуминологическая характеристика образцов, результаты пиролиза Rock-Eval.

Содержания органического углерода $\left(\mathrm{C}_{\text {орг }}\right)$ в породах исследуемой выборки изменяется от 1.37 до 34.3 \%, содержание битумоида в породах изменяется от 0.046 до $2.70 \%$, а отношение этих величин, то есть величина $\beta^{\text {хБ }}$ составляет 1.5-36.3 \%. Из приведённых данных следует, что породы доманика, отобранные для настоящего исследования могут быть отнесены к субдоманикоидам $\left(\mathrm{C}_{\text {орг }}\right.$ до $\left.0,5 \%\right)$, доманикоидам $\left(\mathrm{C}_{\text {орг }}\right.$ 0,5-5\%) и доманикитам (Сорг более 5\%) [Баженова и др., 2004]. Пиролиз по методу RockEval показывает, что исследуемые породы доманика имеют генерационный потенциал $\left(\mathrm{S}_{2}\right)$ от 2 до 180 мг УВ/г породы, то есть здесь присутствуют как породы, содержащие минимальный остаточный углеводородный потенциал и породы с огромным ещё не реализованным потенциалом генерации углеводородов. Величина $\mathrm{T}_{\max }$, характеризующая термическую зрелость ОВ, изменяется от 411 до $477{ }^{\circ} \mathrm{C}$, что соответствует изменению градаций катагенеза от ПК до $\mathrm{MK}_{4}-\mathrm{MK}_{5}$. Здесь и далее используется шкала катагенеза Н.Б. Вассоевича [Вассоевич, 1986].

Рассмотрим данные битуминологических исследований и данные Rock-Eval в совокупности. Зависимость величины HI от ОI для пород доманика свидетельствует о принадлежности керогена изученных пород преимущественно ко II типу (рис. 1, [Тиссо и Вельте, 1981]. Анализ зависимости величины водородного индекса и величины $\mathrm{S}_{2}$ от значения показателя $\mathrm{T}_{\max }$ указывает на протекание прессов генерации и эмиграции углеводородов из пород доманика, сопровождающееся снижением их углеводородного

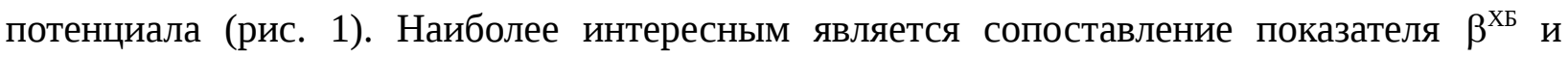
величины $\mathrm{T}_{\max }$. Из рис. 2 следует, что пик содержаний ХБ в породе, приведённых к величине $\mathrm{C}_{\text {орг }}$, приходится на интервал значений величины $\mathrm{T}_{\max } 435-445^{\circ} \mathrm{C}$. Этот максимум и отвечает главной фазе нефтеобразования доманика. Интервал значений $\mathrm{T}_{\max } 445-460{ }^{\circ} \mathrm{C}$ доманиковых отложений в Тимано-Печорском бассейне в настоящее время нами не изучен по причине отсутствия образцов в коллекции. Отметим, что этот интервал $\mathrm{T}_{\max }$ доманикитов «выпадает» и в других известных исследованиях доманика ТиманоПечорского бассейна [Кирюхина и др., 2015].

Использование данных по Волго-Уральскому бассейну (скважина 41-Пешковская) позволяет заполнить эту лакуну. С учётом данных по скважине 41-Пешковская можно полагать, что пик генерации углеводородов и их эмиграции в случае пород доманика завершается к достижению $\mathrm{T}_{\max }$ породы $450{ }^{\circ} \mathrm{C}$. Сопоставление органического вещества 
доманика Тимано-Печорского и Волго-Уральского бассейнов выходит за рамки данной статьи, поэтому ограничимся замечанием, что для настоящего исследования были взяты данные по пиролизу Rock-Eval пород скважины 41-Пешковская [Fadeeva et al., 2015, Смирнов и др., 2018], не выбивающиеся из тренда характерного для пород доманика на графике НІ от $\mathrm{T}_{\max }$ (рис. 1).

\section{Распределение н-алканов и изопреноидов}

Значения отношения $\mathrm{Pr} / \mathrm{Ph}$ в битумоидах доманикоидов колеблются в значительных пределах. Фиксируются колебания данного показателя от 0.86 до 5.2. Согласно [Peters et al., 2005], значения отношения $\mathrm{Pr} / \mathrm{Ph}$ меньше 0.8 - уверенно указывают на восстановительную обстановку в раннем диагенезе, больше 3 - на окислительную, характерную для накопления терригенного органического вещества, а интерпретация промежуточных значений в целом не очень надёжна. Результаты изменений, происходящих в составе алифатических углеводородов битумоида при гидротермальном воздействии на породу, свидетельствуют о возрастании величины отношения $\mathrm{Pr} / \mathrm{Ph}$ с увеличением температуры опыта [Koopmans et al., 1998; Бушнев и др., 2004], в том числе это характерно и для ОВ доманиковых отложений [Бушнев, Бурдельная, 2013, 2015]. Указанные экспериментальные данные не дают оснований полагать, что катагенез может привести к выходу величины отношения $\mathrm{Pr} / \mathrm{Ph}$ из генетически обусловленных, характерных для данного исходного органического вещества, рамок. Таким образом, значения отношения $\mathrm{Pr} / \mathrm{Ph}$ в изученных битумоидах для основной части выборки не позволяют однозначно интерпретировать условия накопления OB как резко восстановительные или окислительные. Повышенные в ряде случаев значения величины отношения $\mathrm{Pr} / \mathrm{Ph}$ вряд ли являются признаками формирования ОВ в условиях терригенной седиментации, так как против этого свидетельствуют данные Rock-Eval, литология пород, другие данные.

Анализ встречаемости значений величины отношения $\mathrm{Pr} / \mathrm{Ph}$ на частотном графике свидетельствует, что основная мода этого показателя для битумоидов доманика лежит в интервале 1,5-2, при этом в наличии и второй максимум встречаемости, отвечающий значениям 4-4,5 (рис. За).

Распределение нормальных алканов в битумоидах доманикитов в общем однородно. Здесь не наблюдается выраженного доминирования четных или нечетных углеводородов. Широко применяемый для оценки нечетности коэффициент СРI (1) в изученных нами образцах варьирует в диапазоне 0.84-1.09, а в среднем составляет величину 0.97. Для выражения характеристик чётности в нашем анализе мы 
дополнительно применили ряд коэффициентов. Значения отношения $2 \times \mathrm{C}_{17} / \mathrm{C}_{16}+\mathrm{C}_{18}$ изменяются в интервале 1.01-1.21. Это значит, что преобладания чётных алканов в этой области не наблюдается никогда, а лёгкое доминирование $\mathrm{C}_{17}$ над соседними гомологами периодически проявляется. Значение отношения $2 \times \mathrm{C}_{23} / \mathrm{C}_{22}+\mathrm{C}_{24}$ изменяются в интервале 0.94-1.18, то есть в этом диапазоне фиксируется как лёгкое доминирование четных, так и нечетных углеводородов. Коэффициент $2 \times \mathrm{C}_{27} / \mathrm{C}_{26}+\mathrm{C}_{28}$ в основной части образцов ниже единицы, что свидетельствует о характерном для верхнедевонских доманикитов незначительному доминированию четных н-алканов в высокомолекулярной области. В частности, в битумоидах наблюдается некоторое повышение концентрации н-алкана состава $\mathrm{C}_{26}$ по сравнению с соседними гомологами. Этот углеводород имеет «изотопную метку» в юрских углеродистых отложениях [Бушнев и др., 2018], а в доманике и продуцируемыми им нефтях - нет [Бушнев, Бурдельная, 2015, Бушнев и др., 2017]. Доминирование чётных алканов, как известно, вообе довольно редко и в целом характерно для ОВ карбонатных отложений и эвапоритов [Peters et al., 2005]. Суммируя, можно сказать, что характерной особенностью н-алканов и изопреноидов битумоидов доманикитов является отсутствие выраженных характерных признаков.

Распределение полициклических биомаркеров неоднократно изучалось в битумоиде доманиковых отложений [Баженова и др, 2008; Бушнев, 2002; Гордадзе, Тихомиров, 2005; Бушнев, 2009; Киселёва, Можегова, 2012; Бушнев, Бурдельная, 2015; Киселёва и др., 2017; Смирнов и др., 2018]. Мы проанализировали полученные нами данные о распределение регулярных $\alpha \beta \beta$ стеранов состава $\mathrm{C}_{27}-\mathrm{C}_{29}$ в битумоидах. Анализ частотного графика (рис. 3b) концентраций стерана $\mathrm{C}_{29}$ продемонстрировал наличие двух не резко выраженных максимумов. Первый из них приходится на интервал 41-43 \%, а второй на интервал 49-51 \%. Частотный график распределения значения показателя $\alpha \beta \beta$ $\mathrm{C}_{27}$, \% имеют отчётливо выраженные признаки бимодальности (рис. 3с). Один из частотных максимумов приходится на область концентраций этого углеводорода 31-33 \%, а второй - более размытый - на область 35-41 \% от суммы стеранов состава $\mathrm{C}_{27}-\mathrm{C}_{29}$.

Термическая зрелость ОВ доманика по данным о распределении стерановых углеводородов варьирует в пределах изученной выборки образцов. Ряд образцов характеризуется значениями отношений используемыми для оценки зрелости такими как $20 \mathrm{~S} / 20 \mathrm{~S}+\mathrm{R}$ и $\alpha \beta \beta / \alpha \beta \beta+\alpha \alpha \alpha$ далёкими от равновесных, а для ряда образцов фиксируется приближение значений данных показателей к величине равновесия. Можно указать, что изменение показателей зрелости по стерановым углеводородам происходит в случае изученной выборки доманиковых пород «скачкообразно», что отчётливо видно на графиках, отражающих зависимость $20 \mathrm{~S} / 20 \mathrm{~S}+\mathrm{R}$ и $\alpha \beta \beta / \alpha \beta \beta+\alpha \alpha \alpha$ от величины $\mathrm{T}_{\max }$ (рис. 
4a-d). Можно заключить, что формальными границами, отделяющими зрелое (ГФН и выше) ОВ доманика от незрелого, являются следующие численные значения основных показателей зрелости OB: отношение $20 \mathrm{~S} / 20 \mathrm{~S}+\mathrm{R}$ для $\alpha \alpha \alpha$ стеранов состава $\mathrm{C}_{29} \geq 0.40$; соотношение $\alpha \beta \beta / \alpha \alpha \alpha+\alpha \beta \beta$ для стеранов состава $C_{29} \geq 0.50$; значение отношения $\beta a / a \beta+\beta a$ для гопанов состава $\mathrm{C}_{30}$ (доля моретана, \%) $\leq 0.10$; отношение $\mathrm{Ts} / \mathrm{Tm} \geq 0.70$. Следует отметить, что данные по самым преобразованным образцам доманика со значениями $\mathrm{T}_{\max }$ выше $460{ }^{\circ} \mathrm{C}$ на графиках (рис. 4) отсутствуют, так как соответствующие биомаркерные коэффициенты здесь не определены ввиду исчезающе низких концентраций соответствующих углеводородов.

Изотопия углерода во фракциях битумоида.

Значения $\delta^{13} \mathrm{C}$ определялись в нефракционированном битумоиде, асфальтенах, смолах, ароматических и алифатических углеводородах. Сопоставление изотопных данных по керогену, битумоиду и его фракциям и термической зрелости ОВ доманика по параметру $\mathrm{T}_{\max }$ показало отсутствие корреляционных зависимостей, что свидетельствует об исключительно генетически обусловленном характере значений $\delta^{13} \mathrm{C}$. Всего такого рода исследования выполнены для 36 образцов битумоида из 16 местонахождений (27 по фракциям для 13 местонахождений). В случае если по битумоиду из одного местонахождения было выполнено несколько измерений полученные данные усреднялись.

Среднее значение величины $\delta^{13} \mathrm{C}$ битумоида доманикоидных пород составило по

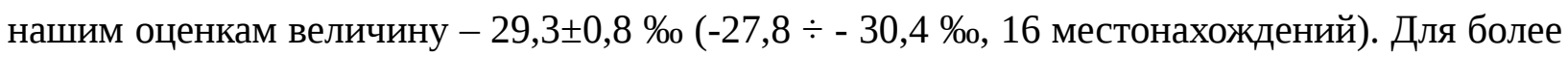
детальных статистических исследований выборки данных немного, однако можно отметить, что частотный график по имеющейся выборке (рис. 5) может свидетельствовать о сосуществование двух - «тяжелого» и «лёгкого» битумоида в изучаемых отложениях. Анализ совокупности полученных изотопных кривых позволяет прийти к выводу о возможном присутствии в изученных разрезах верхнего девона двух изолированных изотопных групп - «лёгкой» и «тяжёлой» (рис. 6). Эти две группы битумоидов доманика в среднем отличаются на 1,5-2 \%о $\delta^{13} \mathrm{C}$. Для группы «лёгких» битумоидов характерна близость изотопного состава ароматической и алифатической фракций, углерод которых заметно легче углерода смол и асфальтенов, а для группы «тяжёлых» битумоидов изотопный состава углерода смол, асфальтенов и ароматических углеводородов весьма схож, при заметном облегчении углерода алифатической фракции. Ранее [Бушнев и др., 2017] были приведены данные об изотопном составе углерода нефтей верхнего девона Тимано-Печорского бассейна, а на основании комплекса данных о составе углеводородов биомаркеров сделаны выводы о возможности отнесения трёх из выделенных пяти групп 
нефтей верхнего девона к генетически связанным с органическим веществом доманиковых отложений. Сопоставление данных по нефтям верхнего девона с «лёгкой» и «тяжёлой» группой битумоидов пород верхнего девона показывает, что изотопный состав доманиковых нефтей соответствует средним значениям ИСУ битумоидов.

\section{Заключение.}

Проведённые исследования позволили установить критерии отнесения органического вещества доманиковых отложений к главной фазе нефтеобразования. Впервые показано, что максимум содержания битумоида в породах доманика приведенного к величине $\mathrm{C}_{\text {орг }}$ приходится на интервал значений показателя $\mathrm{T}_{\max }$ по пиролизу Rock-Eval 435-450 ${ }^{\circ} \mathrm{C}$. Сравнительный анализ данных пиролиза Rock-Eval и коэффициентов зрелости, определённых по составу углеводородов биомаркеров, позволил установить следующие критерии отнесения ОВ доманика к зрелому, достигшему главной фазы нефтеобразования: отношение $20 \mathrm{~S} / 20 \mathrm{~S}+\mathrm{R}$ для $\alpha \alpha \alpha$ стеранов состава $\mathrm{C}_{29} \geq 0.40$; соотношение $\alpha \beta \beta / \alpha \alpha \alpha+\alpha \beta \beta$ для стеранов состава $\mathrm{C}_{29} \geq 0.50$; значение отношения $\beta \alpha / \alpha \beta+\beta \alpha$ для гопанов состава $\mathrm{C}_{30}$ (доля моретана, \%) $\leq 0.10$; отношение $\mathrm{Ts} / \mathrm{Tm} \geq 0.70$.

Анализ данных по изотопии углерода отдельных фракций битумоида доманиковых отложений показал отсутствие зависимости ИСУ битумоида, его фракций, а также керогена от термической зрелости ОВ. Установлено, что в отложениях доманикитов Тимано-Печорского бассейна присутствуют две генерации битумоида - более и менее обогащённые изотопом углерода ${ }^{13} \mathrm{C}$. При этом в составе нефтей это не проявляется, что отражает процесс смешения углеводородов в ходе эмиграции из нефтематеринских толщ.

\section{СПИСОК ЛИТЕРАТУРЫ:}

Баженова Т.К., Шиманский В.К., Васильева В.Ф., Шапиро А.И. Яковлева (Гембицкая) Л.А., Климова Л.И. Органическая геохимия Тимано-Печорского бассейна, СПб.: ВНИГРИ, 2008, 164 с.

Бушнев Д. А., Бурдельная Н. С., Валяева О. В., Деревесникова А. А. Геохимия нефтей позднего девона Тимано-Печорского бассейна // Геология и геофизика, 2017, т. 58. № 3-4, с. 410 - 422.

Бушнев Д.А. Органическое вещество Ухтинского доманика // ДАН, 2009, т. 426, № 4, c. $516-519$.

Бушнев Д.А. Особенности состава биомаркеров битумоида и продуктов пиролиза керогена отложений верхнего девона Печорского бассейна //Нефтехимия, 2002, т. 42, № 5, c. $325-339$. 
Бушнев Д.А., Бурдельная Н.С. Моделирование процесса нефтеобразования углеродистым сланцем доманика // Нефтехимия, 2013, т. 53, № 3, с. 163 - 170.

Бушнев Д.А., Бурдельная Н.С. Нефти и органическое вещество позднедевонских отложений Тимано-Печорского бассейна, сопоставление по молекулярным и изотопным данным // Нефтехимия, 2015, т.55, № 5, с. 375 - 382.

Бушнев Д.А., Бурдельная Н.С., Гончаров И.В., Самойленко В.В., Веклич М.А. Сопоставление органического вещества средневолжских горючих сланцев ВосточноЕвропейской платформы и баженовской свиты по молекулярным и изотопным данным // ДАН, 2018, т. 480, № 2, с. 195 - 199.

Бушнев Д.А., Бурдельная Н.С., Пономаренко Е.С., Зубова (Кирюхина) Т.А. Аноксия доманикового бассейна Тимано-Печорского региона // Литология и полезные ископаемые, 2016, № 4, с. 329 - 335.

Бушнев Д.А., Бурдельная Н.С., Шанина С.Н., Макарова Е.С. Генерация углеводородных и гетероатомных соединений высокосернистым горючим сланцем в процессе водного пиролиза // Нефтехимия, 2004, т. 44, № 6, с. 1 - 13.

Вассоевич Н.Б. Избранные труды. Геохимия органического вещества и происхождение нефти / Н. Б. Вассоевич - М.: Наука, 1986. - 386 с.

Гордадзе Г.Н., Тихомиров В.И. Геохимическая характеристика нефтей и РОВ пород центральных районов Волго-Урала (по УВ-биомаркерам) // Геохимия, 2005, № 11, с. 1208 1223.

Губкин И.М. Минерально-Сырьевая база Урала в свете новейших исследований и разведок и основные задачи ее дальнейшего изучения. Л., Изд-во АН СССР, 1932, 81 с.

Кирюхина Т.А., Большакова М.А., Ступакова А.В. и др. Литолого-геохимическая характеристика доманиковых отложений Тимано-Печорского бассейна // Георесурсы, 2015, т. 61 , № 2, с. 87 - 100 .

Киселева Ю.А., Жеглова Т.П., Дахнова М.В., Можегова С.В., Назарова Е.С., Нечитайло Г.С. Роль доманиковых отложений в формировании залежей нефти в центральных районах Волго-Уральской НГП (Бузулукская впадина) // Геология и геофизика, 2017, т. 58, № 3-4, с. 384 - 397.

Киселёва Ю.А., Можегова С.В. Генетические группы нефтей центральных районов Волго-Уральской нефтегазоносной провинции и их генерационные источники // Нефтегазовая геология. Теория и практика, 2012, т. 7, № 3, с. 1 - 16.

Конторович А.Э. Разработка И.М. Губкиным парадигмы развития нефтяной промышленности СССР в XX веке // Геология и геофизика, 2017, т. 58, № 3 - 4, с. 351 365. 
Полудеткина Е.Н., Смирнов М.Б., Фадеева Н.П., Козлова Е.В. Доказательство формирования органического вещества карбонатных и карбонатно-кремнистых отложений верхнего девона Южно-Татарского свода в условиях постоянной аноксии в фотическом слое // Геохимия, 2017, № 8, с. $730-740$.

Баженова О.К., Бурлин Ю.К., Соколов Б.А., Хаин В.Е. Геология и геохимия нефти и газа. М.: Издательство Московского университета; Издательский центр «Академия», 2004, 415 c.

Смирнов М.Б., Полудеткина Е.Н. Простой способ оценки значимости биопродукции в условиях аноксии в фотическом слое при формировании рассеянного органического вещества пород и нефтей по данным масс-спектрометрии // Массспектрометрия, 2018, т. 15, № 2, с. 93 - 101. DOI: 10.25703/MS.2018.15.23

Смирнов М.Б., Фадеева Н.П., Борисов Р.С., Полудеткина Е.Н. Характеристика органического вещества доманикоидных отложений верхнего девона северных и центральных районов Волго-Урала по составу насыщенных биомаркеров // Геохимия, 2018, № 8, с. 774 - 790.

Смирнов М.Б., Фадеева Н.П., Полудеткина Е.Н. Распространение аноксичных условий в фотическом слое бассейна седиментации при формировании органического вещества доманиковых отложений северных и центральных районов Волго-Уральского НГБ // Геохимия, 2020, т. 65, № 3, с. 277 - 288.

Тимано-Печорский седиментационный бассейн: Атлас геологических карт (литолого-фациальных, структурных и палеогеологических). - Никонов Н.И., Богацкий В.И., Мартынов А.В. и др. - Ухта: Тимано-Печорский научно-исследовательский центр, 2000, 63 л.

Тиссо Б., Вельте Д. Образование и распространение нефти и газа. М.: Мир, 1981, 501 c.

Fadeeva N.P., Kozlova E.V., Poludetkina E.N., Shardanova T.A., Pronina N.V., Stoupakova A.V., Kalmykov G.A., and Khomyak A.N. The hydrocarbon generation potential of the domanik formation in the Volga-Ural petroliferous basin. Moscow University Geology Bulletin, 2015, v. 70 (6), p. 521 - 529.

Flügel E. Microfacies of carbonate rocks: analysis, interpretation and application. Berlin: Heidelberg-Springer-Verlag, 2004, 976 p.

Koopmans M.P., Rijpstra W. Irene C., de Leeuw J.W., Lewan M.D. and Sinninghe Damste J.S. Artificial maturation of an immature sulfur- and organic matter-rich limestone from the Ghareb Formation, Jordan // Org. Geochem., 1998, v. 28, No 7 - 8, p. 503 - 521. 
Peters, K.E., Walters, C.W., Moldowan, J.M., The Biomarker Guide. Cambridge University Press, Cambridge, 2005, 706 p. 
Рис. 1. Изменения показателя НІ доманикитов Тимано-Печорского и ВолгоУральского бассейна (скв. 41-Пешковская) при катагенезе.

Рис. 2. Изменения величины $\beta^{\text {ХБ}}$, \% с ростом катагенеза для доманиковых пород Тимано-Печорского и Волго-Уральского (скв. 41-Пешковская) бассейна.

Рис. 3. Частотные графики биомаркерных показателей для битумоидов пород доманика Тимано-Печорского бассейна.

Рис. 4. Зависимости биомаркерных коэффициентов зрелости от величины $\mathrm{T}_{\max }$.

Рис. 5. Частотный график изотопного состава углерода для нефракционированного битумоида доманика Тимано-Печорского бассейна.

Рис. 6. Изотопный состав углерода по фракциям битумоида доманика и нефтей верхнего девона генетически связанных с ОВ доманика Тимано-Печорского бассейна (3-5 - группы нефтей согласно Бушнев и др., 2017b). Изотопные кривые построены с усреднением: изотопно лёгкий битумоид - 7 местонахождений, изотопно тяжелый битумоид - 6 местонахождений, нефть 3 группы - 18 образцов, нефть 4 группы - 8 образцов, нефть 5 группы - 3 образца. 


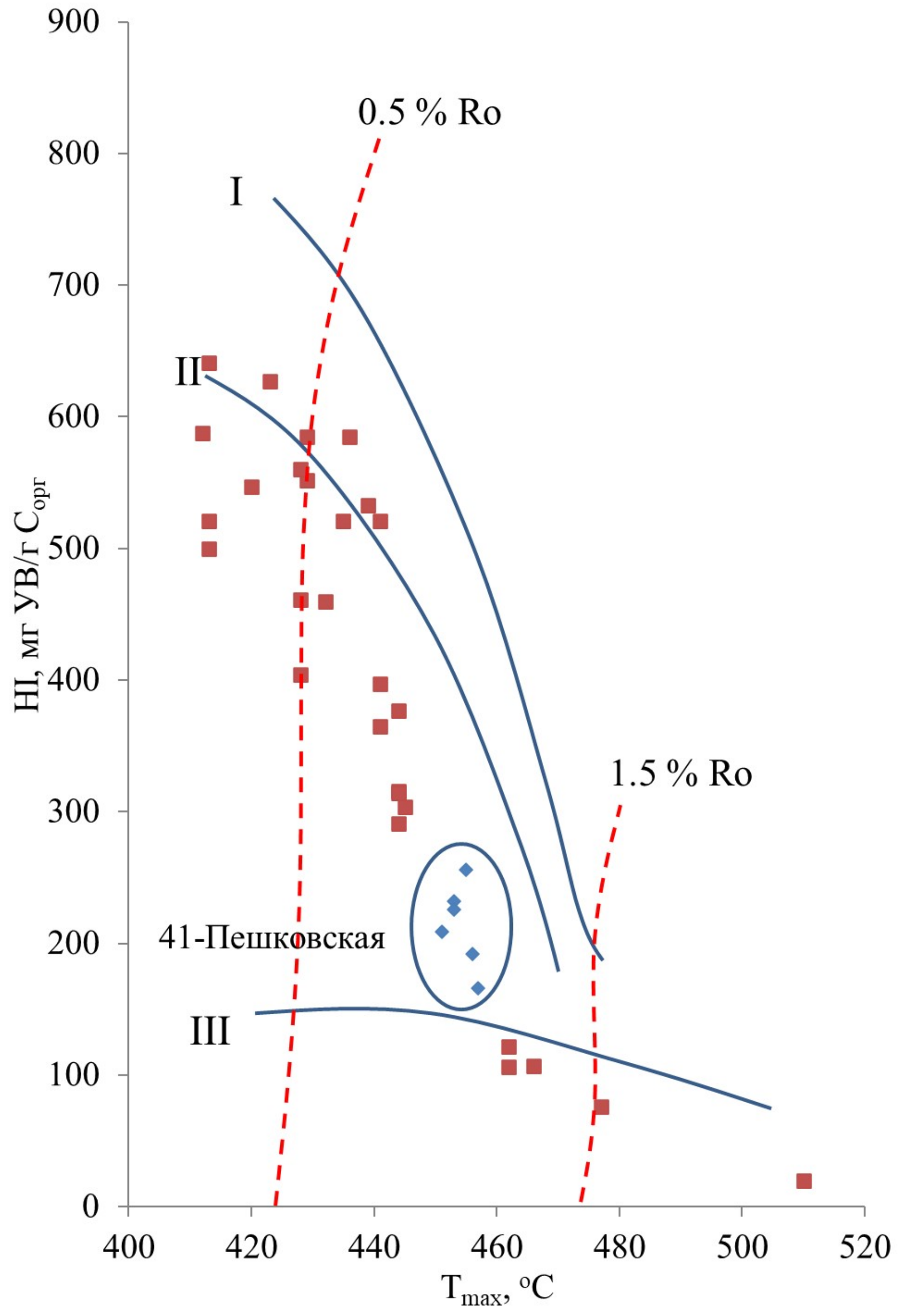




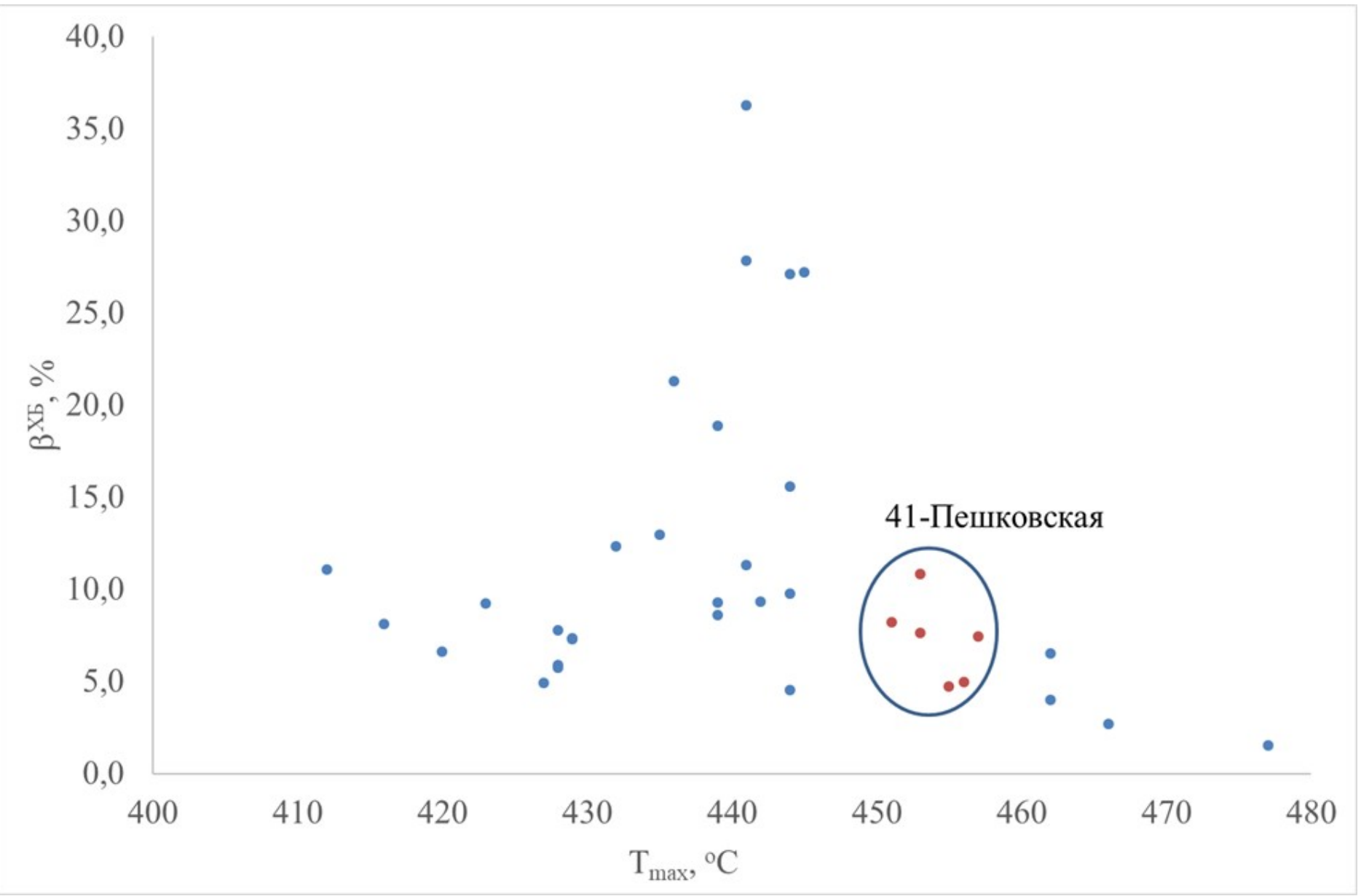



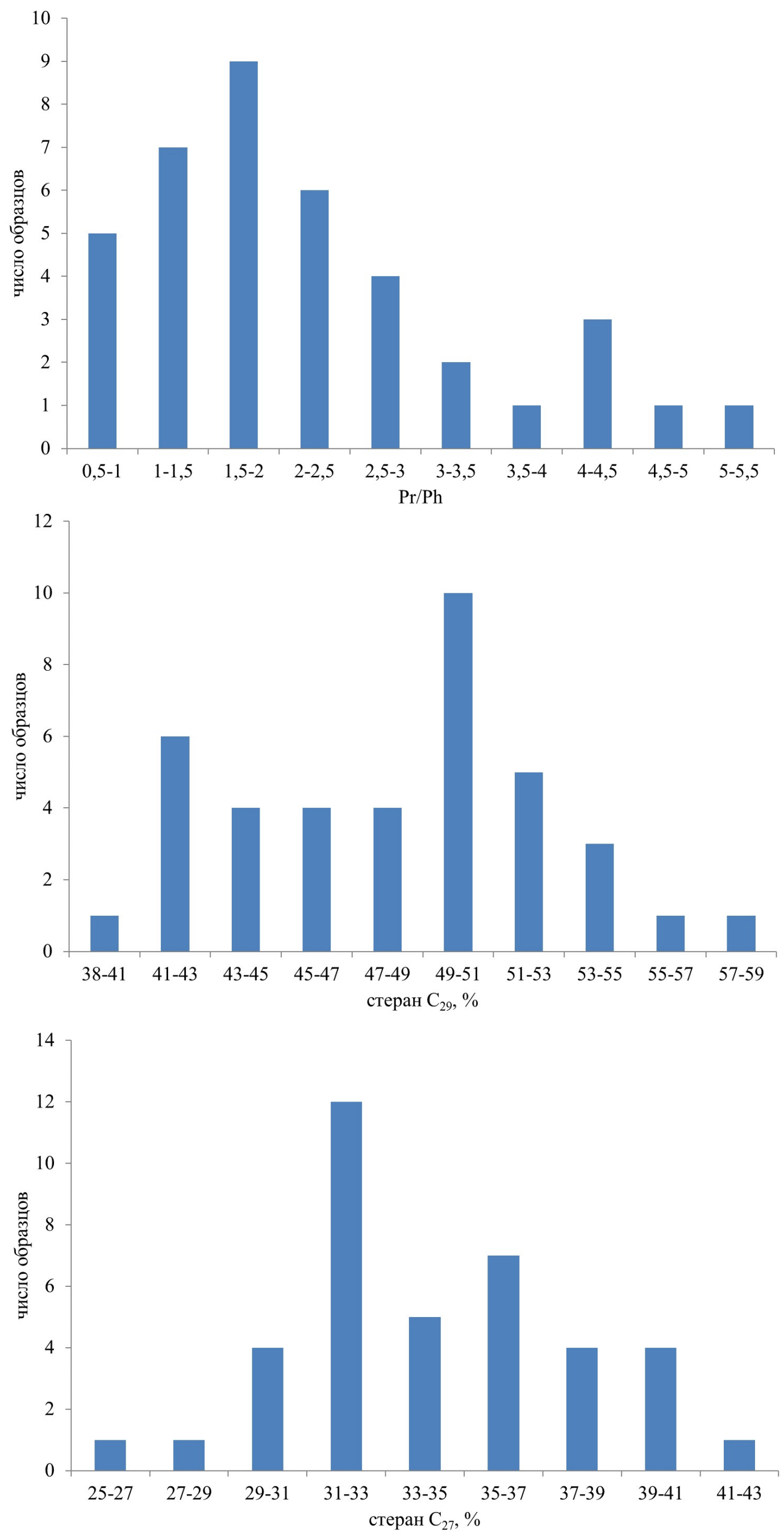

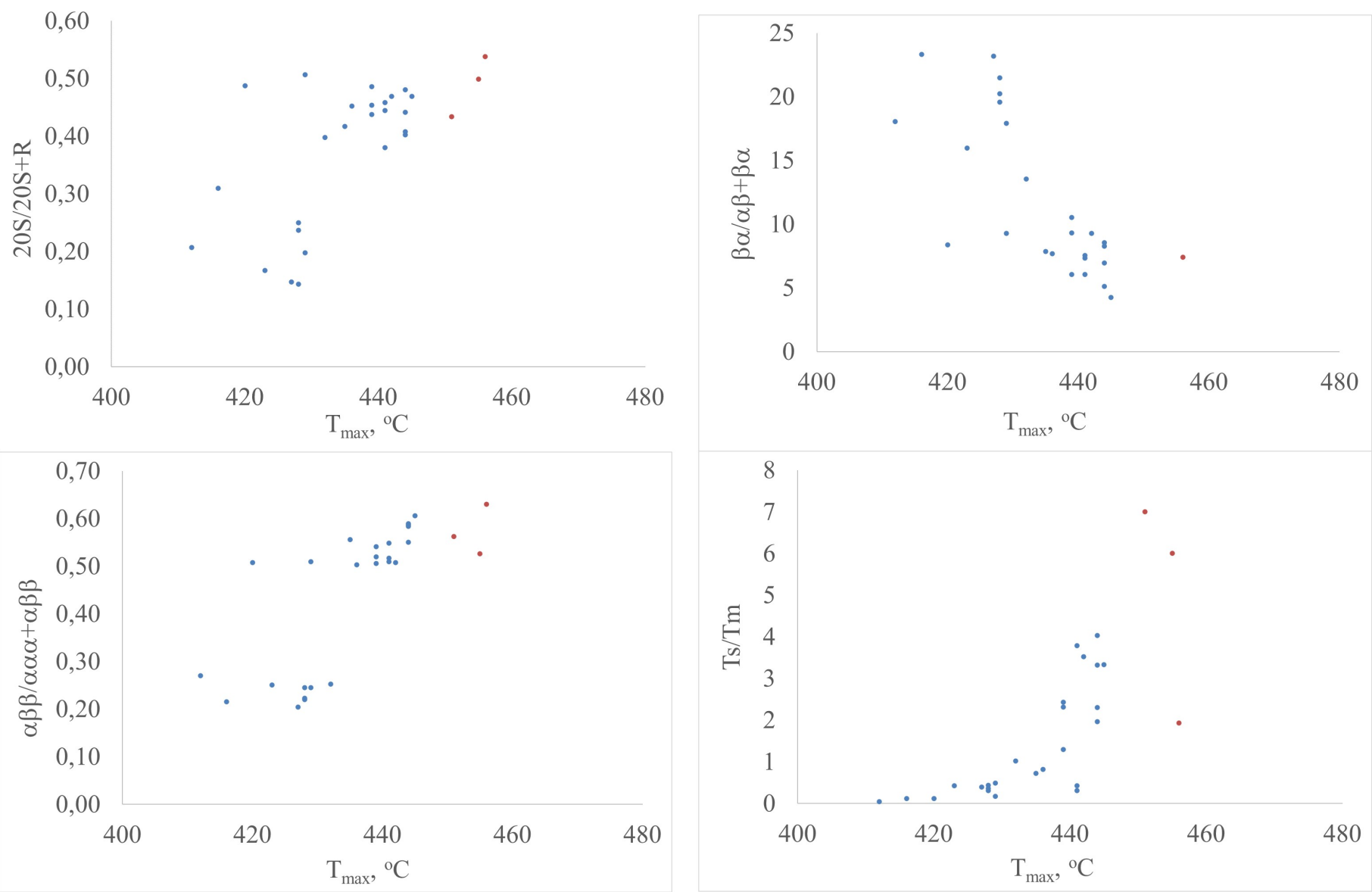


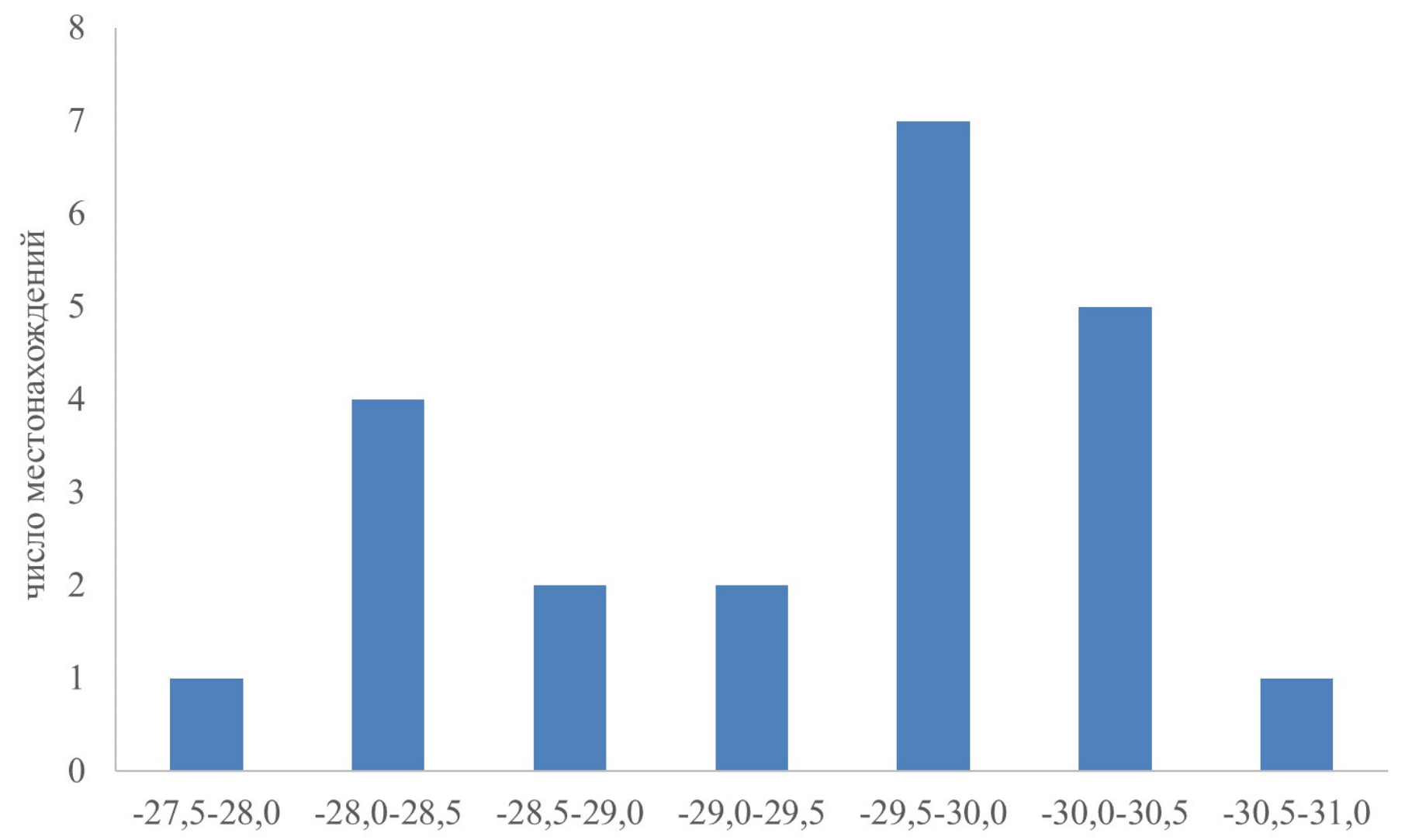

интервал значений $\delta^{13} \mathrm{C}, \%$ битумоида 


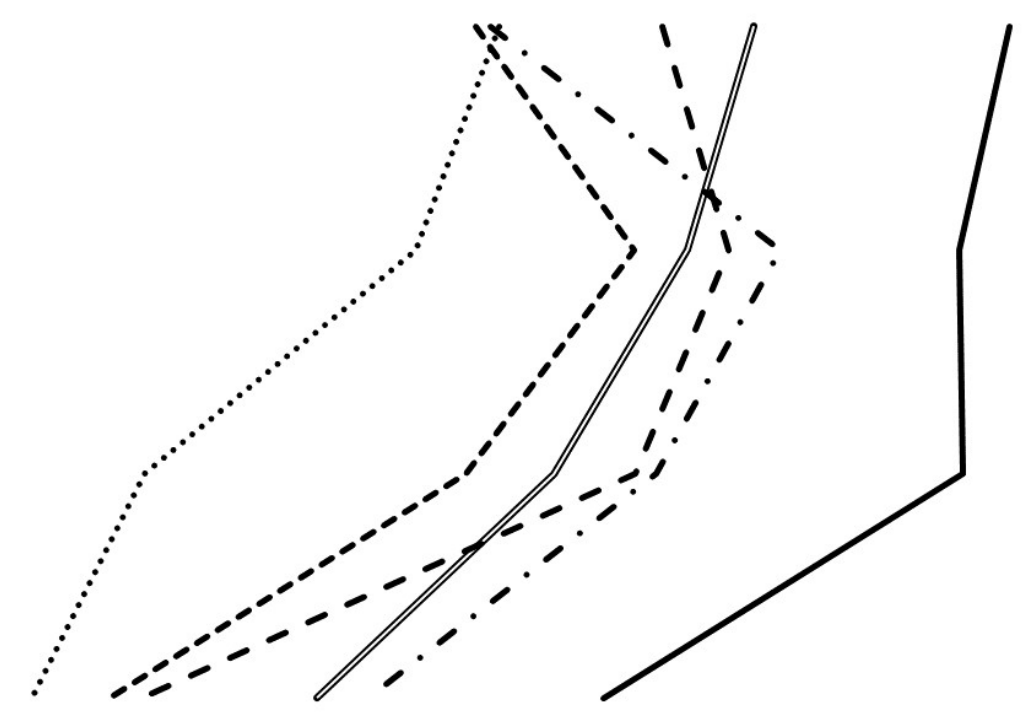

битумоид нефть

\begin{tabular}{|c|c|c|c|c|c|c|c|}
\hline \multicolumn{2}{|c|}{ нефть } & \multicolumn{2}{|c|}{ - -3 группа } & \multicolumn{2}{|c|}{---4 группа } & \multicolumn{2}{|c|}{ - · 5 группа } \\
\hline-31 & $-30,5$ & -30 & $-29,5$ & -29 & $-28,5$ & -28 & $-27,5$ \\
\hline
\end{tabular}

асфальтены

смолы

ароматические УВ

насыщенные УВ 